\title{
Irkçılık Bağlamında 'Elite' Dizi Filminin Eleştirel Söylem Analizi
}

\author{
DOI: 10.26466/opus.816234
}

*

\section{Mustafa Oğuz Yeğin*}

* Niğde Ömer Halisdemir Üniversitesi, Teknik Bilimler Meslek Yüksekokulu, Niğde/Türkiye E-Posta: oguzyegin@ohu.edu.tr

ORCID: $\quad \underline{0000-0002-7912-8415}$

\section{Öz}

Sinema, toplumun içerisinde yaşayan bir sanat olarak yaşadığı toplumdaki eğilimleri, ideolojik kodları ve hassasiyetleri gösterme potansiyeline sahip, ideolojik bir sanattır. Bu perspektiften yola çıklarak Film Sanatının içerisinde çok boyutlu şekillerde duran söylemsel kodlar ve ideolojik orijinleri, sosyokültürel bağlamda, eleştirel bir bakış açısıyla analiz etme firsatı vardır. Bu noktada filmlerdeki ırkçı söylemlere de, eleştirel söylem analizi yöntemini kullanarak ve söylemsel kodları sosyokültürel bağlamda analiz ederek çözümlemeye gitmek mümkündür.Toplumun içerisinde aktif olarak üretilen "irkçı söylem" kodlarının filmlerle de ne şekilde desteklendiğini, Fairclough'un sosyokültürel bă̆lamı ve çok boyutlu yorum sürecini temel alarak yol gösterdiği eleştirel söylem çözümlemesiyle "Elite" dizi filmi özelinde göstermek çalışmanın amacıdır. Filmlerdeki ideolojik ve ırkçı kodların çözümlemeleri sadece eleştirel söylem analizi kullanmakla yetinilmeyip aynı zamanda sinematik kodların da bu ırkçı söylemlere ne şekilde destek olduğunu göstermek amacryla sinematografik analiz yöntemi de çalışmaya eklenmiştir. Etnik ayrımcilı̆̆a dayal filmsel kodların sinematik yapının içine ne şekilde estetize edilerek eklemlendiğini bahsi geçen iki analiz yöntemiyle açı̆̆a kavuşturarak literatüre katkıda bulunmaya çalışılmıştır.

Anahtar Kelimeler: Eleştirel söylem analizi, sinematografik analiz, ırkçılık, ideoloji, elite 
ISSN: 2528-9527

\title{
Critical Discourse Analysis of 'Elite' TV Series in the Context of Racism
}

\begin{abstract}
Cinema is an ideological art that has the potential to show the tendencies, ideological codes and sensitivities in the society it lives in as a living art in society. Based on this perspective, there is an opportunity to analyze the discursive codes and ideological origins in the multidimensional forms within the Film Art in a sociocultural context with a critical perspective. At this point, it is possible to go to the racist discourses in the films, by using the critical discourse analysis method and analyzing the discursive codes in a sociocultural context.It is the aim of the study to show how "racist discourse" codes produced actively in the society are supported with films, "Elite" series with critical discourse analysis based on Fairclough's sociocultural context and multidimensional interpretation process. The analysis of the ideological and racist codes in the movies was added not only to the use of critical discourse analysis, but also to the "Cinematographic Analysis" method to show how cinematic codes support these racist discourses. It has been tried to contribute to the literature by revealing how the filmic codes based on ethnic discrimination are aesthetized and articulated into the cinematic structure with the aforementioned two analysis methods.
\end{abstract}

Keywords: Critical discourse analysis, cinematographic analysis, racism, ideology, elite 


\section{Giriş}

Genel olarak sinema kuramlarının etrafında şekillenen film dünyası her dönem içerisinde farklı paradigmaları ve nüansları içine almıştır. Filmler, hakim olunan dönemin ve coğrafyanın sanatsal ve siyasal algılayış biçimlerinin d1şavurumunun gerçekleştiği devasa bir mecra olmuştur. Film-zihin veya Filmsel imajlar diyebileceğimiz evreni oluşturan; toplumsal sorunlardan, maceraya, felsefeden, dini temalara kadar geniş ölçekte bir film evreninden bahsetmek mümkündür.

Sinema kendi ideolojisini ve bilincini kitlelere empoze edip onları değiştirme ve dönüştürme açısından en az diğer medya araçları kadar etkili ve güçlü bir araç durumundadır. Filmler, anlamı üretip geliştirme yönünden söylemin etkinliğini öne çlkarıp bunu kamera açlarının, sesin, montaj ve efektlerin çeşitli olanakların kullanarak bizleri görsel retoriğin etkin kullanım alanına sahip ve kendine has imgelem dünyası olan cezbedici bir sanatsal atmosfere dahil etmektedir.

Hissedilen gerçekliğin salt yansıması olarak kabul edilemeyecek kadar karmaşık bir gösterim logaritmasına sahip olan film dünyasına, bilinçle bağımlı bir imgelem evrenidir diyebiliriz. Frompton'un (2013, s. 21) film-zihin olarak kavramlaştırdığı bu imgelem dünyasını şu şekilde aktardığı görülmektedir:

"Film-zihin filmin kendisidir. Film-zihnin iki boyutu vardır: kavranabilen insanlar ve nesnelerden müteşekkil temel film-dünyanın yaratımı ile bu filmdünyanın tasarlanması ve yeniden şekillendirilmesi. Bu yeniden yaratıma dayalı tasarlama ve yeniden şekillendirme sürecini, burada "film-düşünme" olarak adlandıracağız."

Film-zihin veya film-düşünme evrenini dolduran art arda birbirini kovalayan ve akışkan bir yapıya sahip film dünyasında imajlar basit bir linear gösterge zincirinden çok daha fazlasıdır. Her bir imajın ideolojik ve felsefik boyutlarının yanında estetize edilmiş imaj mahiyetinin de olduğunu bilmek gerekir. İdeolojik ölçüde filmin tamamen bağımsız bir şekilde hiçbir faktörden etkilenmeyen bağımsız bir orijinden çıktığını söylemek olanaksızdır. Yaylagül'e göre: (2004, s.232) "Sinema filmi, sadece yönetmenin ve diğer çalışanların bir ürünü değil, filmi üretenlerle birlikte içinden çıktığı toplumun bir ürünüdür". Filmin çıktığı toplumun kültürel, dini hassasiyetleri, yaşam biçimleri 
gibi faktörler filmin üreticilerinin de filmi ne doğrultuda üretecekleri hakkında bir ölçüde fikir vermektedir. Filmin üretiminden sonra izleyicilere sunulduğu anda elimizde çözümlenmeye muhtaç birçok anlamsal kod, söylem ve imajlar dünyası bulunur.

Ryan ve Kellner (2010, s.34-35), film dünyasını; toplumsal argümanların, toplumsal yapı bağlantı temsillerinin ve ilişkilerinin kodlandığı bir şifreleme biçimi olarak görmektedir. Böylece filmlerin toplumsal yaşamın söylemlerini çeşitli şekillerde kodlayarak sinemasal figürler aracılı̆̆ıyla izleyiciye aktarması mümkün hale gelmektedir. Sinema toplumdan tecrit edilmiş göstergelerden ziyade toplumun içinde yaşayan insanların bizzat üretimine katkıda bulunduğu bir sanat faaliyetidir. Bütün bunların neticesinde toplumdaki farklı söylemsel düzlemlerin aktarımını da sağlayan imgeler bütünüdür. Ayrıca söylemin analizi açısından, toplumun genel temsillerinin sinemada yansttıldığı düşünüldüğünde bunun toplumun işler düzeniyle arasındaki ilgi kurularak çözümlemeler yapılması gerektiği savunulmaktadır. Bütün bunlar açısından bakıldığında filmlerin içerisindeki esas anlamı çözümlemenin yollarından biri söylem analizidir.

"Söylem kavramı, esas itibariyle toplumsal alanda süregiden iktidar ilişkilerini, dilin anlamlandırma mücadelesi üzerinden okumayı öneren ve böylece toplumsal gerçeklik tanımlarının bu anlamlandırma mücadelesi boyunca sürekli değiştiğini varsayan bir kuramsal yaklaşımın kilit kavramı olarak karşımıza çıkar" (Durna ve Kubilay, 2010, s.48).

Van Dijk' in 'Eleştirel Söylem Analizi' kavramı ise bir yapıtın içindeki söylemlerin iktidar ve ideoloji açısından bağlantısını ortaya koyan bir kavramdır. Haber metinleri, video içerikleri ve web içeriklerini çözümlemek için kullanılan bir yöntem olarak süregelmiştir. Özer'in $(2009$, s.92) tablolaştırdığı Van Dijk' in eleştirel söylem çözümlemesi makro ve mikro yapılara dayanmaktadır. Makro yapılar, tematik yapılar adı altında; başlıklar, haber girişi, fotoğraf unsurlarından oluşurken, şematik yapılar; durum ve yorumdan oluşmaktadır. Mikro yapılar ise; Sentaktik Çözümleme, Bölgesel Uyum, Kelime Seçimleri, Haber Retoriği olmak üzere haberin temel argümanlarından oluşmaktadir.

Bir başka eleştirel söylem analizi görüşü olarak Fairclough ve Wodak (1997) ise sekiz maddede eleştirel söylem çözümlemesinin özünü şu biçimde belirtmiştir (Scollon, 2001, s.141): 
1- Söylem toplumsal eylemin bir biçimidir.

2- Eleştirel söylem çözümlemesi sosyal sorunlara odaklanır.

3- Güç ilişkileri söylemseldir.

4- Söylem kültürü ve toplumu inşa eder.

5- Söylem ideolojik bir işleve sahiptir.

6- Söylem tarihseldir.

7- Metin ve toplum arasındaki ilişki, aracılı bir ilişkidir.

8- Söylem çözümlemesi yorumlayıcı ve açıklayıcıdır.

Fairclough, Eleştirel söylem çözümlemesinde söylemin, siyasi ve içtimai fonksiyonlarını tartışan disiplinler arası bir çözümleme yöntemi olduğunu belirterek, söylem çözümlemesinin belli kuralları olmadığına vurgu yaparak araştırmacıların konu bilgilerine göre farklı yorumlar yapabileceklerine dikkat çeker. Fairclough, sosyokültürel bağlamda, üretim süreci içerisinde olan metnin, toplumsal, ideolojik veya siyasi süreçle ilgili ifadeler ortaya çıkarılarak, yorumlanır ve böylece çözümlemeye gidilmektedir (Akt: Doyuran, 2018, s. 315-316). Fakat özellikle Fairclough'un eleştirel söylem analizini filmsel imajları ve diyalogları irdelemek için kullanmak genel itibariyle çok tercih edilen bir yöntem olmamıştır. Dedeoğlu (2013, s. 42) Eleştirel söylem çözümlemesinin akademide ve literatürde daha çok bir yöntem gibi anlaşılmasının yanında kuramsal bir çerçeve olarak da değerlendirilebileceğini belirtmektedir. "Bu yaklaşım, içinde bulunduğumuz yoğun ilişki ve etkileşimin yaşandığı karmaşık sosyal pratik ve süreçlerin daha iyi anlaşılması ve sorunsallara ilişkin çözüm geliştirilebilmesi yönünde düşünüldüğünde, uygun bir bakış açısı olarak görünmektedir".

Etkileşimci Dünyada Söylem pratikleri içerisinde 'ırkçı söylem' toplumun ve toplumu yönlendiren egemen ideolojilerin kendini ifade biçimi olarak günümüzde önemli bir yere sahiptir.

Her sanat dalının içinde kendini gösterebilen ırkçlığa kavram olarak bakıldığında ise; bireyin ırksal kökenleri nedeniyle başka bir kişiden nefret ettiği veya bir grup bireyin sadece kökenleri sebebiyle başka bir grubu hor gördüğü bir düzeyde gerçekleştiği görülmektedir. Toplumlarda geçmişte bir süre, bir grup ikinci grubun üyelerinin (bireylerinin) bir şekilde daha alt tabakada olduğuna karar verdi. İlk grubun üyeleri ikinci gruptakilerle ilgili 
basmakalıp inançlar yarattı. Gerçeklikte temeli olmayan bu basmakalıp yargilar, yalnızca önyargılı grubun üyelerinin kalıp yargıların doğru olduğu konusunda ısrar ettikleri için bir tür gerçek statüsü kazanmaya başlamıştır (Charles ve Wilson, 2005, s. 11-13). Neticede rrkçllık olgusu toplum özelinde ideolojik bir anlama bürünerek günümüz toplumsal pratiklerinde, sanatta ve sinemada sunulan önemli bir kavram haline gelmiştir.

Daha önceden de belirtildiği gibi bir bakıma Sinema toplumsal pratikleri ve toplumsal söylemleri, olanakları doğrultusunda film-zihin yapısıyla ve imajlarla anlatan güçlü bir mecradır. Bu bakımdan film içerisindeki karmaşık anlam kodlarının ve art arda gelen ideolojik imajların çözümlenmesi için 'eleştirel bir bakışla' söylem çözümlemesi yapmanın gerekliliği ön plana çıkmaktadır. Bunu yaparken sadece filmin içerisindeki söylemleri çözümlemek yeterli olmayıp sinemanın doğasına ait biçimsel yapının da incelenmesi gerekli olmaktadır. Genel olarak bakıldığında haber metinlerinin ve medya metinlerinin nasıl anlamlı, belirli bir dizilimde olan yapıları varsa filmlerin de sinematografiyi (mizansen, kamera açısı, ışık, ses) içeren belirli prensiplere sahip algoritması bulunmaktadır. "Film yeni zamansal ve mekansal kent ilişkilerini analiz etme ve onları bu mekanlarda yaşayanlara anlamlı biçimlerde gösterme kapasitesine sahip tek biçimdir" (Wayne, 2011, s. 50). Bu bağlamda Fairclough'un eleştirel söylem analizini temel alarak, tıpkı toplumsal bir bağlam kapsamında bulunan metnin içinde duran ve açığa çıkarılmayı bekleyen dil yapıları gibi film çözümlemesi yapılacaktır. Film çözümlemesi kapsamında 2018 yılında yapılan İspanyol dizi filmi Elite'nin Filistinli Müslüman Nadya karakterinin özellikle koleje başladığı süreci gösteren ilk beş bölümünde yaptı̆̆ı yoğun ırkçı söylemler baz alınmıştır. Dizi filmin anlatısının içerisinde gömülü biçimde bulunan 'ırkçı söylemlerin' diyaloglarla ve sinematografik açıdan ne şekilde desteklendiği irdelemek ve anlamak makalenin amacı olmaktadır.

\section{Irkçılık Olgusu}

Dünyanın çeşitli coğrafyalarında farklı dönemlerde ortaya çıkmış olan ve kendi etniğinden olmayan insanlara yönelik ayrımcılık veya aşağılayıcı davranışları içeren 'ırkçlık' kavramı günümüzde de devam etmektedir. Farklı ülkelerde yapılan çok çeşitli çalışmalar ırkçılık hakkında bize bilgi vermektedir. Bu çalışmalardan bazılarının isimleri şu şekildedir: 
“Dovidio and Gaertner, 1986; Essed,1991; Katz and Taylor, 1988; Omi and Winant, 1986; Schuman, Steeh, and Bobo, 1985; in the UK: Barker, 1981; CCCS, 1982; Gilroy, 1987; Husband, 1982; Jenkins and Solomos, 1987; Miles, 1982; Mullard,1985; in West Germany: Hoffmann and Even, 1984; in the Netherlands: Essed, 1991; van Dijk, 1987a; in France: Taguieff, 1988; and in Europe generally: European Parliament, 1986" (Dijk, 1991, s. 25).

Dünya ölçeğinde kurumsallaşmış sosyal ilişkiler biçimlerini detaylı analiz etmeden, sosyal ve ekonomik kurumların ırkçllı̆ı toplumun sosyal hayatından sanatına kadar artırmadaki etkilerini anlamadan ırkçılı̆̆ tam anlamıla yorumlamak mümkün olmamaktadır. Irkçllık tarihinin görmezden gelinerek modern formları anlamaya çalışmakta gerçekçi olmayacaktır. 17. ve 19. yy arasında Afrika kökenli insanların Amerika'ya göç ederek burada sömürgeciliğin gelişmesi, rrkçllık fitilinin ateşlenmesi ve modern rrkçlık mefhumunun ortaya çıkmasının kronolojik olarak art arda geldiği söylenebilmektedir. Bu bağlamda sömürgeci devletlerde kölelik, tahakküm ilişkileri, sınıf farkları gibi çeşitli kümelenmeler temelinde ırkçılık, ABD başta olmak üzere gelişimini sürdürmüştür. Ekonomik ilişkiler temelinde köle olarak $\mathrm{ABD}^{\prime}$ ye göç etmiş milyonlarca Afrikalı, beyaz Amerikalı insanlara hizmet etmiştir ve bu perspektifte yüzlerce yıldır bu ekonomik ilişki devam etmiştir. Dolayısıyla yüzlerce yıl önce beyaz Amerikalılara hizmet eden Afrikalı kökenli göçmenlerin torunları da günümüzde değişen ekonomik ilişkiler temelinde halen bir şekilde modern kölelik denilebilecek düzeyde hizmet etmeye devam etmektedirler. Geçmişten günümüze değin sürdürülen bu ekonomik ilişkileri yalnızca ekonomi temelli açıklamak gerçekçi bir bakış olmayacaktır. Bu noktada "1rkçı ideolojilerin" sonucu olarak kölelik sisteminin doğduğu ve halen değişen ve dönüşüme uğrayan ekonomik ilişkilerin içinde de Modern anlamda ırkçı ideolojilerin olduğunu belirtmek gerekmektedir (Bulmer ve Solomos, 1999, s.9-11).

Irkçılı̆ın kökenlerine baktığımızda temel olarak tahakkümü elinde bulunduranların yani sanayi toplumlarının kurulmasıyla birlikte özellikle sanayilerini erken kurmuş toplulukların diğer kökenlerden gelen insanlara karşı etnik ayrımclıkta bulundukları bilinmektedir. Sanayiyle birlikte yükselişe geçen Batı toplumları yani Avrupa ülkeleri ve Amerika Birleşik Devletleri başta olmak üzere çeşitli devletlerin kurdukları ekonomi tabanlı işleyişin çarklarını döndürmek için farklı coğrafyalardan alınan işçiler daima farklı bir kategoriye dahil edilerek indirmegeci bir davranışla karşılanmışlardır. 
Tarihsel açıdan bakıldığında batılı olmayan ve genellikle doğu ülkelerinden gelen insanların en başta olumsuz ve önyargılı değerlendirilmesi için öncelikli kıstas cilt rengi ve bedensel görünüm farklılıklarında algılanmıştır. On sekizinci ve on dokuzuncu yüzyıllarda bu gerçek ya da hayali farklılıklar daha sonra farklı 'ırklar' hakkında halkların biyolojik sınıflandırma yaptığ bir tabu haline gelerek, 'irkların' doğal olarak ilişkili ahlaki veya sosyo-kültürel özellikleri hakkında sözde bilimsel argümanlar tarafından desteklenmiş, genellikle 'beyaz' ırkın diğer ırklardan üstün olduğu sonucuna yol açmıştır (Dijk, 1991, s.26-27). Özellikle gücü ve ideolojiyi elinde bulunduran Batıdaki beyaz ırkın doğudan ve güneyden gelen kitlelere yönelik önyargılı tutumu ırkçılığı önemli ölçüde artırmıştır. Edward W. Said'e göre "Batı bilgi-iktidar ilişkisinden hareketle, kendini tanımlamak, sömürgeci niyetlerini haklı göstermek ve bu amacını gerçekleştirmek adına hayalî bir Doğu üretmiştir" (Çoruk, 2007, s.193). İnsanın temel doğası gereği ve kimliğini inşa ederken oluşturduğu öteki kavramı sınırları dahilinde doğal olarak tanımladığı öteki hep dışarıdan gelenler yabancılar olmuştur. Batının yabancısının ise Doğulular olduğunu söylemek yanlış olmayacaktır.

Avrupa'da başta Almanya olmak üzere farklı ülkelerde neo-nazileri ve türevlerini destekleyen birtakım siyasi oluşumlar ve gruplar doğudan gelen mültecileri baskı altına alarak çeşitli eylemlerde bulunmuşlardır. 1992 yılında Avusturya'da yabancılara karşı "önce Avusturya" adlı kampanyası başlatılarak mülteciler dışlanmıştır. Benzer şekillerde Fransa'da "Fransa'nın Yeniden Doğuşu İçin üç yüz Tedbir" ve Belçika'da "Vlaams Blok" adlı programlar ile birlikte etnisiteye dayalı ırkçı ayrımlar yapılarak yabanclar nefret duygularıyla birlikte dışlanmışlardır. Avrupa Birliği'nin iltica ve göç yasalarını değiştirerek sığınmacılara yönelik zorlu önlemleri almasıyla birlikte ırkçıllğın yükselen eğrisinin devam ettiği görülmektedir. Avrupa'da ırkçı partilerin ve grupların giderek yükseldiği bir dönemde ABD'de "11 Eylül 2001'de" ikiz kule saldırılarının olması da popülist düşman üretme söylemlerini artırmıştrr. (Fekete, 2009, s. 1-2) Özellikle olmayan düşmanı tasarlama ve üretme faaliyetleri kapsamında popülist grupların hayal güçlerine katkıda bulunabilecek şekilde yaşanan 11 Eylül Saldırıları ırkçılı̆̆ı Avrupa ve ABD'de yükselen bir söylem haline dönüştürmüştür. Böylece "Terörist" gibi kelimelerin özellikle Batı ülkelerindeki ırkçı söylemler bağlamında Müslümanlara yönelik yapılan ağır söylemlerden biri haline geldiği görülmektedir. Ötekinin kurgulanmasında ve kendilik kimliğinin ön plana çıarılmasında etkin bir faktör 
olarak yorumlanabilecek ideoloji mefhumu da ırkçıllğa bazı durumlarda destek olmaktadır.

"Maxime Rodinson'un Avrupa Kitabında ikna edici bir şekilde gösterdiği gibi İslam'ın tasavvufu, İslam'ın ve Müslüman öteki'nin imgesi de Batı Avrupa'nın ideolojik ve teolojik birliğinin kurulmasına yardımcı oldu" (Geisser, 2004, s. 36)

Ötekinin çarpitılarak ve türlü söylemlerle özünden uzaklaştırılarak indirgemeci bir tavırla düşmanlaştırıldığı toplumlar kendi kimliklerini koruyabilecekleri fikrini daima muhafaza etmişlerdir. Irkçı söylemlerin aynı zamanda mensup olunan din dışında ten rengi, fiziki görünüş, bulunulan ülkedeki dili kullanma aksanı gibi faktörlere bağlı olarak da kullanıldığı görülmektedir.

\section{Sinema Filmlerinde İdeoloji ve Irkçı Söylemler}

Irkçı bağlamda üretilen söylem kodlarını sadece toplumun gündelik hayatı içerisinde değil aynı zamanda toplumun çarpıcı bir göstergesi haline gelmiş olan, önemli bir sanat alanı durumunda bulunan, Sinema sanatında da görmekteyiz. Filmler üretildikleri coğrafyanın belirli kültürel göstergelerini ve hassasiyetlerini anlatan sanatsal araçlardır. Düşünülen durumun belirli perspektiften gösterilmesi noktasında bir araya gelmiş temsili imaj öğeleri bazı ideolojileri bize aktarmaya çalışırlar.

“Tematik görenekler -eril kahramanlık serüvenleri, romantizm arayışı, kadın melodramı, kurtarıcı şiddet öyküleri, ırkçılığa ve suça ilişkin klişeler vb.gerçekliği toplumsal değer ve kurumlarla bağlantılandırarak bunların değişmez bir dünyanın doğal ve apaçık göstergeleri olarak algılanmasını sağlar. Bu görenekler seyirciyi belli bir toplumsal düzenin temel varsayımların benimsemeye ve bunların içerdiği akıldışılık ve adaletsizlikleri gözardı etmeye alıştırır" (Ryan ve Kellner, 2010, s. 18).

Sinema sanatı bağlamında oluşturulan filmlerin şiddet, nefret söylemi ve ırkçılık gibi mefhumlarla yönetmen tarafından estetize edilerek ve aynı zamanda normalleştirilerek tek çare buymuş gibi seyircilere empoze edildiği görülmektedir. Sanat kapsamında yalnızca masumane bir tabii akış içerisinde olan imajlarmış gibi hissedilen filmler esasında toplumun ırkçılık gibi bazı yönelimlerini ideolojik kodlarla da empoze etmektedirler. 
Film dünyası gerçeğin yönetmenin süzgecinden geçerek ideolojik bazı argümanlarla biçimlendirildiği bir dünyadır. İdeoloji ise çeşitli biçimlerde üzerimizde tahakküm kurmaktadır. Foucault'un da belirttiği gibi toplumda bulunan belli davranış kalıplarından ve kaçınılması gereken sakıncalı kesimlerden uzaklaşma ve onlardaki çeşitli düşünce kalıplarının kendi kimliğimizde olmasını istemeyerek aslında kimliğimizi ideal olarak oluşturulmuş düzene ve sisteme göre biçimlendirdiğimiz açıktır. Bu biçimlendirme neticesinde bizlere dayatılan bir ideolojiyi de kimliğimize entegre ettiğimiz görünmektedir. Böylece "başka bir kimliğin öznesi" konumuna otomatik olarak geçmiş oluruz. Arzumuz gibi hissettiğimiz ve sahiplendiğimiz fakat içeriği boşaltılmış ve deneyimlemelerimizden uzak bir kimlik sahibi olarak aslında ideolojinin yansımasını isteyerek kabul etmişsözde özneler oluruz (Foucault, 2003 s. 1516).

Filmler genel itibariyle ideolojik olarak toplumu yöneten genel tahakkümün uzantılarını taşıyarak ve onları çeşitli dönüşümlere uğratarak yansıtan bir sanat aracıdır. Yeri geldiğinde de tahakküm ve değerlere karşı duruşlar sergileyebilen bir sanat olabilmektedir. Ayrıca Ranciere'nin tanımladığ gibi, sanatsal eserin bizi çeşitli yanılsamalara sokarak kendimizi "özne" gibi hissettirmesi nedeniyle veya yönetmenin derdini iyi anlatamaması gibi sebeplerle sanat eserinin/filmin "nedenden sonuca", "niyetten neticeye" giden yolunun her zaman açık olmayabileceği unutulabilmektedir. Yine bundan dolayı kendini aktif karar verici özne olarak gören ve sanatsal eserin ilhamından giderek karşı duruş iradesine sahip/tahakküm karşıtı birey olabildiğini savunan sanat algılayıcısının, bir yanılsama içerisinde olabileceği düşünülmelidir. Egemen düzenin dışına sanat eserini algılayarak çıkıldığı sanrısı neticesinde aktifleşmiş gibi görünen bireyler aslında oldukları yerde durağan ve pasif konumlarını sağlamlaştırmaktan öteye gidememektedirler. Bütün bunlardan dolayı filmler dahil birçok sanat dalının paradoksal bir yapısının olduğu ve genel tahakkümün devamını sağlatabilen ideolojik kodlar alanıyla çevrelenmiş olduğu sonucuna da varılabilmektedir (Ranciere, 2010, s. 49).

Geçmiş dönemde üretilen Hollywood veya Avrupa menşeili filmlerden günümüz filmlerine kadar en masumane görünen filmlerde dahi bize ilk bakışta kendilerini göstermeseler de ideolojik anlamların harmonik şekillerde sanat çerçevesine sığacak biçimlerde dönüştürülmüş ve sembolize edilmiş halleri vardır. Ryan ve Kellner'ın da belirttiği gibi Sinema sanatı, temsilleri 
kullanarak ve psikolojik süreçlerden de faydalanarak ideolojik kodlarla bezediği filmlerle bize neyin, ne şekilde olması gerektiği veya ne şekilde sürdürülmesi gerektiğiyle ilgili bilinç aşılaması yapmaktadırlar. Bilinç aşılaması filmlerde "metaforların" etkileşim gücüne dayanarak, "ideal olanın inşası" şeklinde yapılmaktadır (Ryan ve Kellner, 2010, s. 39).

Filmlerde çeşitli temsiller düzeyinde karşımıza çıkan "1rkçı söylemler" Amerikan Sinemasında eskiden beri var olmuştur. Western filmlerinde sıklıkla gördüğ̈̈müz Kızılderilileri sanki insan dışı bir grup varlıkmış gibi gösteren filmlerin yanı sıra yakın tarihli Amerikan sinemasında da güncel örnekler mevcuttur. Ryan ve Lenos'un tespitlerinden yola çıkıldığında, örneğin 1993 yılında çekilen Sonun Başlangıcı (Falling Down) filminde beyaz Amerikalı figüründe gördüğümüz Bill karakteri son derece ırkçı özelliklere sahip bir karakter görünümündedir. Kendi kötü maddi durumunun sorumlusu olarak gördüğü Asyalı veya Latin göçmenlere karşı ırkçı davranışlar sergileyen hatta şiddet uygulayan Bill'in neden ırkçı davranışlar sergilediği filmde meşru bir yapıyla ve çeşitli simgesel kodlara büründürülerek olumlanmaktadır. Bu simgelerin içerisinde Asyalı bir dükkan sahibinin eski ırkçı bir koda atfen dükkan penceresinin sarı renkle gösterilmesi veya domuzcuk figürüyle beraber gösterilmesi öne çıkmaktadır. Ayrıca gerek Latin kökenli çete üyeleri gerekse Asyalı dükkan sahibi, bakımsız ve pis bir görünümle sembolize edilirken, Bill karakteri ise beyaz Amerikalı olarak düzgün giyimli ve düzgün aksanlı olarak gösterilir. Sinematografik açıdan bakıldığında ise ışık kullanımı, Bill karakterini gösterirken onun ırkçı paradigmalarını meşrulaştırır bir mahiyette aydınlık tasvir edilmiş, diğer göçmen kökenli tipler ise parçalı aydınlatma kullanılarak esrarengiz bir hava içerisinde sunulmuştur. Filmde ırkçı olmayan Amerikalı karakterler de olmasına rağmen esasında ideolojik ve görsel kodlardan da anlaşılabileceği üzere beyaz Amerikalı Bill'in saldırgan ve ırkçı davranış kalıpları olumlanmıştır ve film seyirciyi ırkçı prensipleri anlamaya yöneltmektedir (Ryan ve Lenos, 2012, s. 247-250).

Batı menşeili filmlerin yöneldiği ırkçı söylemler kimi zamanlarda ise ırkın milli ve dini değerlerlerinin kötüymüş gibi gösterilerek, değişime uğratılarak farklı ideolojik kodlarla gösterilmesi durumudur. Bu hususta tarihsel gerçekler ideolojik değişim ve dönüşümlere uğrayarak, sinematografik kimi araçlarla desteklenerek sunulmuştur. 2014 yılında gösterime giren Amerikan yapımı Dracula Untold (Dracula: Başlangıç) filmi bu tezi destekler niteliktedir. Fatih Sultan Mehmet'in Eflak beyliğinin Voyvodası konumunda bulunan 
Vlad Tepes (Dracula)'ya yaptığı sefere değinen filmde çeşitli ırkçı söylemler ön plandadır.

Osmanlı İmparatorluğunu insani olmayan bir ırkın temsilcisi gibi gösteren film karşı tarafta bulunan Vlad'a ise halkının ve Hristiyanlığın yegane koruyucusu olarak "ilahi bir güç" yüklemiştir. İlahiliğin karşısında duran ırk olarak barbar ve insanlık dışı atfedilen ırk ise Türklerdir.

“Her zaman köklerini kaybetme tehlikesiyle karşı karşıya olan günümüz bilinci, ilkel zamanların doğal, bilinçsiz, içgüdüsel bütünlüğü arasında bir köprü atar" (Jung, 1980, s.174).

Tarihsel, Arketipsel bir yanılsamayla tarihi gerçeklerden uzaklaşarak son bulan filmde Vlad Tepes "müzakereci", "kurtarıcı", üstün ırka ve dine sahip "ideal Hristiyan" olarak gösterilirken Türkler "istilacı" ve "vahşi" bir ırk olarak idealize edilmiştir. Batının ideal Türk imgelemi bu filmle sinematik kodlar çerçevelendirmesiyle ırkçı söylemler kullanılarak sembolize edilmiştir.

İspanyol Sinemasına bakıldığında ise beyaz perdeye yansitılan görüntü özellikle 1950'lerden itibaren hep aynı tarzda olmamıştır. Önceleri Sahra Altı Afrikasındaki İspanyol sömürge deneyimiyle bağlantılı filmler çekilmiştir. Bu filmler "uygarlaştırma projesi" adı altında propaganda temelli görüntülerin ön plana çıktığ1 varyasyonlarla kendini göstermiştir. Göçmen işçilerin oluşturduğu ekonomik sıkıntılar, Avrupa'nın bir parçası olan İspanyol kimliğine kültürel olarak verdiği zararlar gibi mefhumlar da filmlerde gösterilen çeşitli imgeler olmuştur. Daha sonra ülkenin kollektif hafızasına yabancı bir unsur olarak kazınan Afrikalılarla birlikte, Müslümanlar ve Latin Amerikalı göçmenler de ötekileştirilerek nesne boyutuna indirgenmişlerdir (Blanco ve Lopez, 2017, s. 572-581).

Bat orijinli filmlerde bulunan etnosantrik sinemasal kodlar İspanyol Sinemasında da kendini göstermektedir. Irksal izolasyonun meşruiyetini sorgulayan Montxo Armendariz, Imanol Uribe gibi yönetmenlerin çektiği filmler kadar direkt olarak ırkçı söylemlerde bulunan filmlerde dikkat çekicidir (Goncalves, 2016, s. 52).

1981 yapımı Mariano Ozores' in yönetmenliğindeki Es Peligroso Casarse a 60 Los (60 Yaşında Evlenmek Tehlikelidir) filminde ise ırkçı tavırların bilinçaltı süreçlerine kodlanmış hali gözler önüne serilir. Siyahi insanlardan şüphe ve korku duyan bir iş insanının şanssızlığını siyahi insanlara bağlaması bu filmle siyahi bir insan gösterilerek rasyonalize edilir (Blanco \& Ortega , 2018, s. 139). 
Jose Luis Cuerda tarafından çekilen 1989 yapımı Amanece Que No Es Poco (Gün Doğumu Basit Bir Şey Değildir) adlı komedi filminde de ırkçılığın unsurlarına rastlanır. Köyde geçen komedi filminde İspanya'nın denizaşırı eski kolonilerinden gelmiş latin kökenli ve İspanyolca konuşan insanlara bile yerel halk tarafından ötekileştirici bir dille muhatap olunur (Blanco \& Ortega ,2018, s. 144).

1999 Miguel Santesmases'in yönetmenliğindeki La Fuente Amarilla (Sarı Çeşme) isimli filmde İspanya'da bulunan suç şebekesi olarak Çin mafyası gösterilerek aslında ülkedeki suç unsurları ve Çinli göçmenler arasında otomatik bir bağ kurulmuş görünmektedir.

\section{Netflix Yayın Platformu ve Sinematik Söylemler}

Konvansiyonel analog yayıncllı döneminde ve sonrasinda gelişen teknolojiyle birlikte çeşitli ilerlemeler kaydeden dijital yayıncılık 2000'li yılların başından itibaren kendini sürekli yenileyerek göstermektedir. İletişim teknolojilerinin gelişimine paralel bir şekilde ilerleyen internet teknolojileri de daha önce sınırlı olan etkileşimlilik ve interaktiflik gibi özelliklerin doğmasını sağlamıştır. 2007 yılından günümüze kadar gelindiğinde Mubi ve Netflix gibi platformların internet üzerinden belirli ücretler karşılığında sinema filmlerini ve çeşitli dizileri izleyicilerle buluşturmaktadır.

Netflix dijital yayıncllı platformu, belirli üyelik protokolleri gerektiren bir sistemdir ve internetin bağlı bulunduğu bilgisayar, mobil telefon, televizyon gibi cihazlarla izlenebilmektedir. Birden fazla profil oluşturma, favori film listesi düzenleme, çeşitli dil ve altyazı seçenekleriyle birlikte büyük bir interaktif platformdur. Bu platform dünya genelinde 165 milyona ulaşan izleyici sayısını da bünyesinde barındırmaktadır (Webtekno, 2021).

Yeni bir izleyici mecrasına dönüşen ve filmlere ulaşma alışkanlıklarımızı değiştiren dijital platformlar toplumsal eğilimleri de gözler önüne sermektedir. Yayınlanan dizi ve filmlerin içeriklerine bakıldığında birbirinden farklı ülkelerin yapımlarını bulabildiğimiz Netflix platformunda görünüşte çok sesli bir içerik ortamı bulunmaktadır. Kullanıcılar çok sesli içerik ortamından dilediği ülke yapımını seçerek eğilimlerini göstermektedirler. Ayrıca bir ülkede çok fazla ön plana çıan bir içerik farklı ülkelerde fazla tercih edilmeyebilmektedir. Bu perspektiflerden bakıldığında dijital platformların konvansiyonel sinema seyircisinin izleme alışkanlıklarını da değiştirdiği söylenebilir. 
"Yaşadığımız toplum göstergeler, imgeler ve gösterge sistemleriyle daha da ilgilenir hale gelen, gitgide 'sinemalaştırılan' bir toplum. Dolayısıyla gerçeklik gitgide daha çok sahneleniyor, toplumsal üretim ve gündelik deneyimler de sahnelenen sinemasal emsallerine göre değerlendiriliyor" (Diken ve Laustsen, 2011, s.24). Sinemalaştırılan toplumda hayatın toplumsal akışı içerisinden titizlikle seçilerek ekrana yansitılan her anlam kodunun arkasında görünenden çok daha fazlası barındırmaktadır.

İmgeler çeşitli anlamlar taşıdığından dolayı, bir kültürün ve kurumların görüşlerini, değerlerini yansitırlar. Toplum çevrimiçi olarak tasvir edilen görüntülerin türüne bağlı olarak, marjinalleştirilmiş bir kültür hakkında olumlu veya olumsuz bir şekilde harekete geçebilmekte veya düşünebilmektedir. Sonuçta, marjinalleştirilmiş bir grubun sinematik dünyada nasıl tasvir edildiği, görüntülerin retorik tepkisi olarak izleyiciler üzerinde nasıl etkilerde bulunduğunu keşfetmek yani Netflix' in tasviriyle etkileşim düzeylerini düşünmek gerekmektedir (Plothe ve Buck, 2019, s.142-143).

Adorno ve Horkheimer'ın kurumsallaştırdığı kültür endüstrisi bağlaminda düşünüldügüünde dijital platformlarda üretilen filmler insanların yegane sosyal ihtiyaçlarıymış gibi yansıtılmaktadır. Sahte bilinçle birlikte kapitalist toplumun tüketicileri bu görsel içerikleri tüketerek özde sistemin yeniden üretimine ve kontrol mekanizmalarına katkıda bulunmaktadırlar (Adorno, 2007, s. 52-53).

Kültür endüstrisi kavramından yola çıkılarak aslında Netflix'in geleneksel çerçevedeki izleyici kalıplarını kırarak sözde demokratik çeşitliliğe sahip içerik ortamı oluşturduğu söylenebilir. Fakat bu oluşturulan ortamla birlikte aslinda mevcut sistematik ideolojinin aracı olarak yapımcının ön planda olduğu bir yeniden üretim algoritması görülmektedir. Bu bağlamda Netflix' in daha önceden yayına soktuğu Bodyguard dizi filminde kadın bombacı Müslüman olarak temsil edilirken yine aynı platformda yer alan Homeland adlı dizi filmde ise şiddet ve terör unsurlarılla birlikte Müslümanlar sembolize edilmiştir. 


\section{Yöntem}

\section{Fairclough'un Eleştirel Söylem Analizinin Filmlere Uygulanması ve Sinematografik Analiz}

İdeolojik olarak çeşitli biçimlerde Sinema Filmlerinin içerisine gömülü durumda bulunan söylem kodlarını açımlayabilmek için “Eleştirel Söylem Analizi" gerekli olmaktadır. Söylemin ideolojik bağlantılarını ve güç ilişkilerini Elite dizi filmi özelinde analiz edebilmek adına bu yöntem tercih edilmiştir. Filistinli Nadya Karakterinin İspanyol okuluna ilk başlama sürecinde yaşadıklarının söylemsel çözümlemesi, "ırkçı söylem" bağlamında, karakterin okula uyum sürecinin bulunduğu ilk beş bölüm baz alınarak yapılmıştır. Çalışmada filmdeki ırkçı söylemsel kodları çözümleyebilmek için Fairclough'un “Eleştirel Söylem Analizi” yöntemi ve ideolojinin filmde hangi sinematik teknik ayrıntılarla sunulduğunu göstermek için ise "Sinematografik Çözümleme" yöntemi kullanılmıştır.

Film sanatı kamera ve birçok sinema tekniği kullanılarak yapılan bir sanattır. Fakat filmler, toplumdaki "gerçekliği" olduğu gibi göstermek yerine, yönetmenin içinde büyüdüğü toplumda ve kendi içerisinde oluşturduğu “ideal ideolojisini" yansıtarak gösterme eğilimindedir. "Bir film çekmeye başladığımız andan, daha ilk çekimden itibaren, şeyleri gerçekten oldukları gibi değil fakat ideolojinin süzgecinden geçtikleri haliyle yeniden üretme zorunluluğuyla karşı karşıya kalırız. Bu, üretim sürecindeki her aşamayı içerir: Konular, stiller, biçimler, anlamlar, anlatı gelenekleri; bunların hepsi genel ideolojik söylemi vurgular. Film kendisini kendisine sunan, kendisiyle konuşan, kendisini öğrenen bir ideolojidir" (Comolli ve Narboni, 1976, s. 25). Filmlerdeki ideolojik imaj uzantıları etrafında sürekli dönen söylemler, açımlanması gereken kodlar olarak kendini göstermektedir. Bu aşamada filmdeki söylemin nasıl çözümleneceği, modelinin ne olması gerektiği giriş bölümünde ayrıntılı olarak bahsettiğimiz gibi ayrı bir tartışma konusu olmaktadır. Söylem analizlerine sıklıkla konu olan ırkçılık, güç ilişkileri veya cinsiyetçi ilişkiler üzerine yapılan çalışmalarda görüleceği gibi Batılı söylemlerin hangi konulara odaklandığına tanıklık etmek pek zor olmamaktadır. Bu tarz çalışmalardan hareketle, Avrupa ve Amerika'da genel olarak söylem yapılarının neler olduğunu kestirmek oldukça kolaylaşır. İlk olarak haber analizleri içindeki 
ideolojik veya ırkçı yapıları ortaya çıkarmak ve çözümlemek maksadıyla çıkarılan söylem çözümlemesi sonra roman metinlerini çözümlemek için de kullanılmıştır. Daha sonraları kimi araştırmacılar tarafından Film metinlerini çözümleyerek ideolojik kodları açımlayabilmek maksadıyla da kullanılmıştır.

Farklı biçimlerde uygulanan "Eleştirel Söylem Analizi" yöntemleri ve birbirleri arasındaki ilişki çok boyutlu bir etkileşime sahip görünümdedir.

Fairclough'a göre ideoloji bağlamında daha önce yapılan birçok çalışmada tahakküme ve iktidara bağllık ilişkilerinin nasıl işlediği sıkça sorgulanmıştır. Ayrıca toplumsal ilişkilerde bulunan etnik grupların birbirleri arasındaki ilişkilerinde ideolojinin rolüne ilişkin çeşitli sorgulamalar yapılmıştır. İdeolojinin işleyişi hakkında deterministik bir durum söz konusu olmamakla birlikte ideolojinin eleştirisi çeşitli sosyal gruplar için ve etnik yapılar için bir mücadele alanı olmaktadır. Eleştirel Söylem Çözümlemesi ve dolayısıyla "eleştirel dil farkındalığı" ideolojik eleştirinin de önemli bir yolu durumunda konumlanmaktadır (Fairclough, 1995, s.17-18).

İdeolojinin birçok alanla etkileşim halinde olması ve çok boyutlu şekilde farklı alanlara yayılması ESA yönteminin de çok katmanlı bir hal almasına sebep olmuştur. Fairclough (1993, s.225) Söylem analizi yapmak için net olarak çerçevesi çizilmiş bir kurallar olmadığına dikkat çekerek, bunun yerine araştırmanın kendi doğasına uygun söylem şekillerine göre farklı yaklaşımlarla sonuca gidilebileceğini belirtir. Fairclough, (1995, s.96) yazılı metinlerdeki dil biçimleri veya sözel olarak var olan dil biçimleriyle toplumun "sosyal süreçlerinin doğası" arasında sistematik bir ilişki kurularak bu sürecin incelenmesi gerektiğinden bahseder. Böylece dilin içerisinde açık olmayan ideolojik bağlantıları ve güç bağlantılarını eleştirel bir tarzda yorumlamak mümkün olabilmektedir.

Fairclough üç boyutlu söylem anlayışı ve bu bağlamda oluşturduğu üç boyutlu EleştirelSöylem Analizi yöntemini şu şekilde ifade etmektedir: "Söylem ve herhangi bir özel uygulama örneği, aynı anda (i) sözlü veya yazılı bir dil metni, (ii) söylem pratiği (metin üretimi ve metin yorumu), (iii) sosyokültürel uygulama" (2013, s.151). Bu yöntemde dil metninin dilsel tanımı (üretken ve yorumlayıcı) söylemsel süreçler ile metin arasındaki ilişkinin yorumlanmasını ve söylemsel süreçler ile sosyal süreçler arasındaki ilişkinin açıklanmasını içerir (Fairclough, 2013, s.152). Filmlerdeki söylemler çözümlenirken de dilsel metnin sosyal bağlamdaki ilişkileri hakkında önemli ipuçlarına 
ulaşmak mümkündür. Cinsiyet ilişkilerinden doğan söylemlere veya tahakküme dayalı söylemlere bu dilsel metnin üç boyuttaki analiziyle ulaşılabilmektedir. Öncelikle söylemde bulunan kişinin bulunduğu yer özellikleri yani söylemin sosyal bağlamda üretildiği yer, söylemin ne şekilde kullanıldığ hakkında fikir verebilen sözcük yapıları gibi bağlamlar üzerinde durulmaktadır. İkinci aşamada ise işlenmemiş bir halde bulunan metinler toplumsal ilişkiler, ideolojik ve güç ilişkileri gibi değişkenlere dayanılarak metnin altında yatan bağıntılar ortaya çıkartılarak yorumlanır. Böylece söylemin filmlerde de hangi kodlarla hangi düzlemde ortaya çıkartıldığı analiz edilebilir. Son aşamada ise daha geniş bir perspektif olan söylemin sosyokültürel boyutlariyla (Durumsal, Kurumsal, Sosyal) göz önünde bulundurularak metni/söylemi üreten yazarın, hangi ideolojik kodlara sahip olduğu ve hangi amacı taşıdığı analiz edilir. Heterojen ve karmaşık sosyal ilişkilere dayanan söylemler mevcut sosyokültürel ve ideolojik kodlara ulaşmamızı sağlamaktadırlar (Fairclough, 2013, s. 151-153). Film sanatında da ana unsur olarak görüntünün yanı sıra karakterler ve tiplerin diyalogları da geniş yer tutmaktadır. Bu sebeple sinema filmlerini de zengin görsel ve metinsel kaynaklar olarak değerlendirmek yanlış olmayacaktır. Dolayısıyla Fairclough'un söylem analizinde bahsettiği, "metinler" ve "sosyokültürel" söylem pratiklerini, Film Dünyasındaki diyaloglardan hareketle, çeşitli filmler bağlamında, analitik bir düzlemde, eleştirel olarak yapabilmemiz mümkündür. Bu yöntemle filmsel argümanları metin olarak ele alarak eleştirel bakış açısıyla söylem analizi yapmak filmin sunduğu ideolojik anlamlara da ulaşmamızı sağlayacaktır. Bu doğrultuda "1rkçı söylemleri" de ideolojik sunum çerçevesinde eleştirel söylem analiziyle irdelememiz mümkün olacaktır.

Söylemlerin yanı sıra Film Dünyasının temelini oluşturan görsel imajların da "Elite" dizi filmi özelinde ne şekilde biçimlendirilerek ırkçı söylem kodlarına destekte bulunduğu "Sinematografik Analiz" perspektifinde değerlendirilecektir. Sinematografi hem çerçevenin uzamsal özelliklerini hem de film ortamının zamansal ya da zamana bağlı karakterini içerir. Klasik anlatılı kurgu filmleri öyküler anlatır, belgeseller olayları anlatır ve gözlemler, avangard filmler yeni ses ve ses kombinasyonları yaratır; tüm bu farklı film türleri izleyiciden önce uzayda ve zamanda ortaya çıar (Pramaggiore ve Wallis, 2008, s. 134). 
"Sinematografi, görsel doku ve anlatı yapısı filmde tematik işlev görür. Uygarlığın yüzey tabakasının hemen altında vahşet ve hayatta kalma savaşının yattığı, bu yüzden, doğadaki kaosun patlak vermesini önlemek için güçlü liderlere ve sağlam bir düzene gerek olduğu gibi muhafazakâr temaların altını çizmekte çeşitli biçimsel yöntemlerden yararlanılır" (Ryan ve Kellner, 2010, s. 115).

Tüm bunlar ele alındığında filmlerin de birçok söylem gibi "1rkçı söylemleri" ele alabileceği ve bu söylemlerin bir metin analizi gibi söylemsel kodlar çerçevesinde çözümlenebileceği ayrıca söylemin film sanatının kendi dünyasına mahsus sinematografik kodlarla da desteklenebileceği ve bu kodların çözümü için de ek olarak "Sinematografik Analiz" unsurlarına başvurulabilecektir.

Bordwell ve Thompson "Sinematografik Analiz" için sinematografinin unsurlarını genel hatlarıyla üç başlık altında incelemektedir, bunlar: Çekimin fotografik görünüşü, çekimin çerçevesi ve çekimin süresidir. Çekimin fotografik görünüşüyle filmde ışığın ne kadarının kaydedileceği, tonu ve hızı anlatılmaktadır. Çekimin çerçevesi ise "sadece nötr bir sınır değildir; belli bir bakış açısını dayatmaktadır". Bu bakış açılarını yönetmen bize film yoluyla dayatır ve kadraj içerisine giren nesnelerin sorgulanmasını sağlatmaktadır. Çekimin süresiyle ise yönetmenin filmde geçen durumlara atfettiği anlam kodlarına istinaden olayı veya durumu gerçek zamana yakın bir kayıt süresiyle kesmeden göstermesi veya yavaş çekimle birlikte olayın dramatik değerini artırarak göstermesi kastedilmektedir (Bordwell ve Thompson, 2008, s. 162-207). "Her durumda, film yapımcısı tonalite aralığını seçebilir, hareket hızını değiştirebilir ve perspektifi dönüştürebilir" (2008, s. 162).

Netice olarak ırkçı söylemlerin filmler aracılığıyla söylemsel şekillerde ve sinematografik kodlar kullanılarak filmsel imajlar manipüle edilerek sunulması söz konusudur, çalışmada amaç bu kodların hangi temalar üzerinden işlevselleştirildiğini irdeleyerek ortaya çıkarmaktır. 


\section{Elite Filmi}

\section{Filmin Künyesi}

Tablo 1. Film Künyesi (İmdb, 2020)

\begin{tabular}{ll}
\hline Yönetmen & Dani de la Orden, Ramón Salazar, Jorge Torregrossa ve Sílvia Quer \\
\hline Yapımc1 & Francisco Ramos \\
\hline Senarist & Darío Madrona, Carlos Montero, Carlos C. Tomé, Jaime Vaca, Breixo Corral, Abril \\
& Zamora, Almudena Ocaña, Andrés Seara \\
\hline Oyuncular & Itzan Escamilla, Miguel Bernardeau, Arón Piper, Omar Ayuso, Álvaro Rico, Mina El \\
& Hammani, Ester Expósito, Ainhoa Santamaría \\
\hline Müzik & Lucas Vidal, Matthew Jordan Leeds \\
\hline Dağıtıcı & Zeta Ficción, Netflix \\
\hline Türü & Suç, Dram ve Gerilim \\
\hline Çıkış Tarihi & 5 Ekim 2018 \\
\hline Sezon/Bölüm & 3 Sezon/8'er Bölüm \\
\hline Dili & İspanyolca \\
\hline
\end{tabular}

\section{Elite Filmi Analizi}

İspanyol menşeili bir yapım olan Elite dizi filmi ad olarak dünyada birçok dilde olduğu gibi İspanyolcada da "seçkinler" anlamını taşımaktadır. Dilimize de girmiş olan "elit" sözcügüne "seçkinler" olarak sözlük anlamıyla bakıldığında ise şu şekilde anlamları bulunduğu görünmektedir.

"Benzerleri arasında niteliklerinin yüksekliğiyle göze çarpan, üstün, mümtaz, güzide, mutena; Bir toplumda saygin ve etkin mevkilerde bulunan ve toplumun eğitim, ekonomi, siyaset, askeriye, din, sanat vb. alanlarıla ilgili etkinliklerin denetimini elinde tutan kişi veya grup" (Tdk, 2020). Film ad itibariyle kendi kimliğini "seçkin" veya "seçilmiş" gibi kapsamlarda gören politik veya idari olarak etkin vasıflara sahip ve çeşitli gruplar etrafında kümelenmiş bir grup insanı anlatacağını da göstermektedir.

Film, biri Müslüman olmak üzere üç gencin okullarının dayanıksızlıktan yıkılması neticesinde inşaat firmasının burs vermesiyle "Las Encinas" adıyla anılan seçkin iş insanlarının çocuklarının okuduğu okulda eğitime devam etmeleriyle başlamaktadır. Varlık sahibi ve seçkin ailelerin çocuklarının oluşturduğu çeşitli gruplar etrafında kümelenmiş öğrenciler genel itibariyle hem fiziken hem de zihinsel olarak eğitime açk bir görünüş sergileyememektedirler. Sosyalleşme faktörünün başat olarak konumlandırıldığı, fiziksel tatminkarlı̆̆ın ve buna istinaden günlük olarak yaşanacak fantezilerin ön plana çık- 
tığı, popülaritenin el üstünde tutulduğu bir ortamda "okul" mekan bağlamında anlamından çok uzak bir işleve sahiptir. Anlamlar dünyasında eğitim mecrası bağlamında görülebilecek okul, film dünyasında işlevsizleştirilerek zengin ve ergen özeliklerini bir arada barındıranların ütopik dünyalarını besleyen bir yakın çağ ikonu olarak standartlaştırılmıştır. Yakın çağ ikonu olarak okul ergen kitlenin sosyalleşebilmelerini sağlayacak, onları eğlendirecek ve fantezilerini doyurma kapsamında kalması gereken bir yerde konumlandırılacaktır. Sosyal etkileşimin ve toplumun yapı taşı olan aile kurumu filmde dışlanarak yerine anlam aşınmasına uğratılarak sunulmuş bir "okul" öne ç1kartılmıştır. Toplumsal düzenin ve bilgeliğin olağan akışını devam ettirecek temele sahip olan eğitim kurumları yakın çağda toplumsal fonksiyonalizmini kaybetme zorunluluğu içerisinde kalmış, eğitime dair içeriği boşaltılarak yalnızca şatafatlı görünüme sahip olarak fiziki varlığını sürdürebilir bir değerle sunulmuştur. Zorunluluk temelinde fiziki olarak iyi bir yerleşkeye sahip ve dijital donanımları bünyesine kazandırabilmiş “Las Encinas" görünürde iyi bir eğitim vaadi sunmasına rağmen gerçekte gençlerin jargonunu sahiplenmiş, onlara eğlendirici ve geleneksel eğitim anlayışından çok ötesini karakterize etmiş ve aslında gençlerin idealleştirdiği ütopik dünyalarına erişebilecekleri yegane mecra konumundadır.

Varlıklı ailelerin çocuklarının ön planda olduğu, çarpık ilişkilerle bezenmiş ve Batı modernist yaşamının hiç kanaatkâr olmayan doyumsuz karakterleriyle çevrelenmiş bir ortamda ülkeye sonradan gelen mültecilerinde yapacağ tek şey ya bu çevreye uyum sağlamak ya da tecrit olma yaptırımına maruz kalmaktır. Genç yaşlarda tecrit olmayı göze alamayan ve bunun için varlıklı ailelerin çocuklarının kurduğu eğlence uzantılı cemiyetlere kardeşiyle birlikte dahil olan Filistinli Nadya karakterinin Müslüman ve muhafazakar sınırları, mülteci olan orijinleri kısmen kaybetmiş görünümleri zengin eğlence grup üyeleri tarafından her yöne çekilebilecek niteliktedir. Irkçı söylemlerin bazı söz kalıplarıyla dizi filmin tüm bölümlerine serpiştirildiği, Müslüman ve muhafazakar kimlikler üzerinden yapılan ırkçılığın ideolojik olarak da görsel dokuyla desteklenerek, estetize edilerek sunulduğu ve normalleştirildiği görülmektedir. 


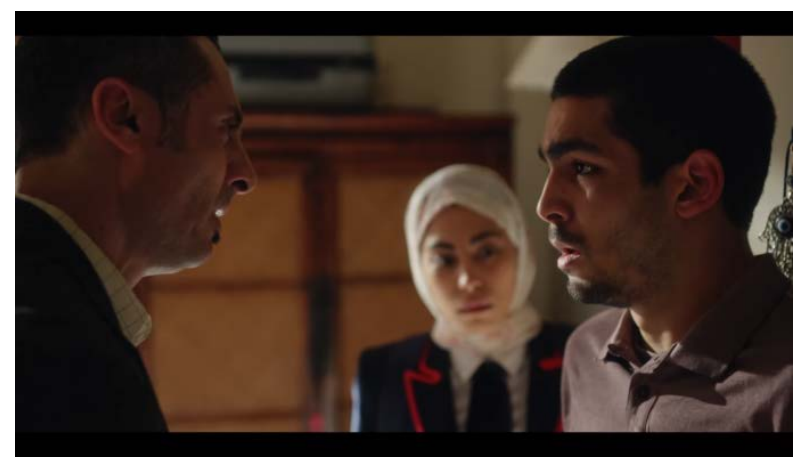

İmaj 1. Nadya Karakterinin Íkinci Planda Kalması

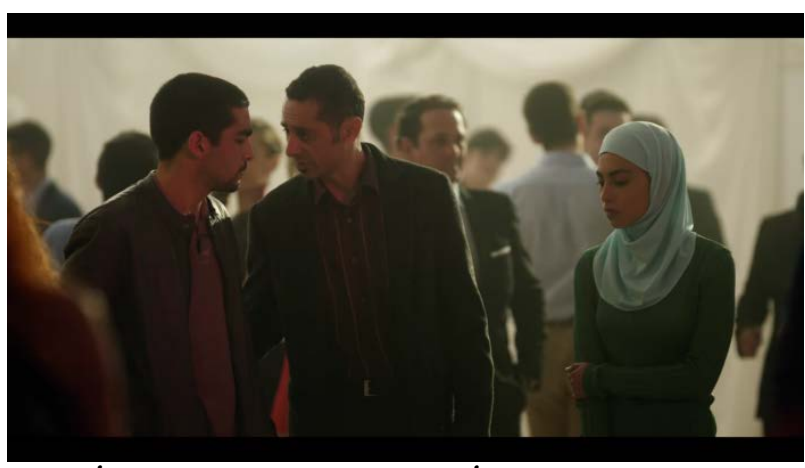

İmaj 2. Nadya Karakterinin Íkinci Planda Kalması

Nadya karakterinin filmdeki yansitılma şekillerine bakıldı̆̆ında öncelikle, ailesine ve geleneksel yaşam değerlerine bağlı, muhafazakar, dini yönden İslam'ın kurallarına uyum sağlamaya çalışan bir portrede sunulmuştur. Bunların yanı sıra eğitim yönünden okulda derece yaparak hedeflerine ulaşmaya meyilli ve hurslı öğrenci görünümündedir. Ailesinin istek ve emirlerine riayet eden, sınırlarını belirlemiş ve bu sınırların dışına çıkma lüksüne sahip olmayan karakterdir. Sinematografik olarak karakterin kadrajlamasina dikkat edildiğinde ise genellikle ailevi diyaloglarda yönetmen tarafından ikincil planda kalmasının vurgulanması amacıyla flu veya kadrajın sağında, çerçevenin dış tarafına yakın biçimlerde sunulmuştur. Bu teknikle verilmek istenen, ideolojik kod ve sosyokültürel bağlamda vurgusu yapılan şey, diğer İspanyol "özgür" ailelerin çocuklarının aksine bir mülteci ve Müslüman olan Nadya'nın özgürlüğ̈̈nün ailesi tarafından baskı altına alındığgı, sıkışık bir hayat düzleminde zevklerinden mahrum kalabilecek kadar sınırlandırıldı̆̆ıdır. 
Böyle bir yaşam alanında Nadya, çizginin dışına yakın olmakla birlikte çizgi dışına çıktığında yaptırıma maruz kalabilecek bir çerçevede betimlenmiştir.

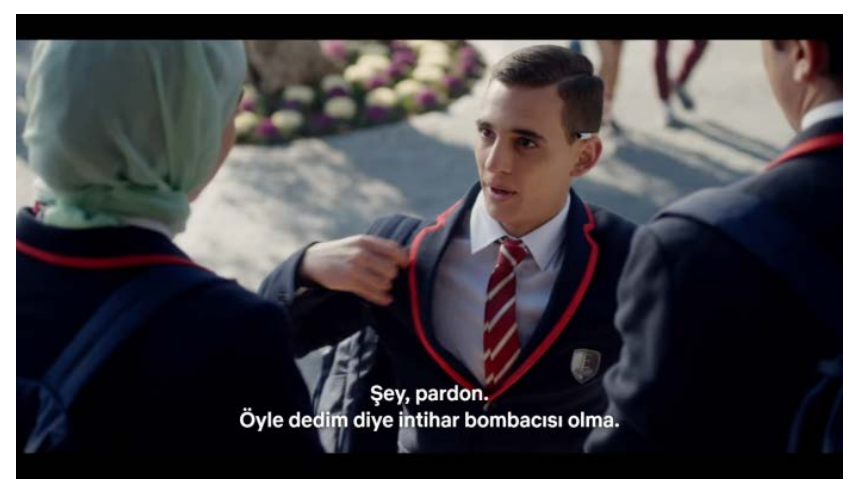

İmaj 3. Christian Karakterinin Irkçı Söylemi

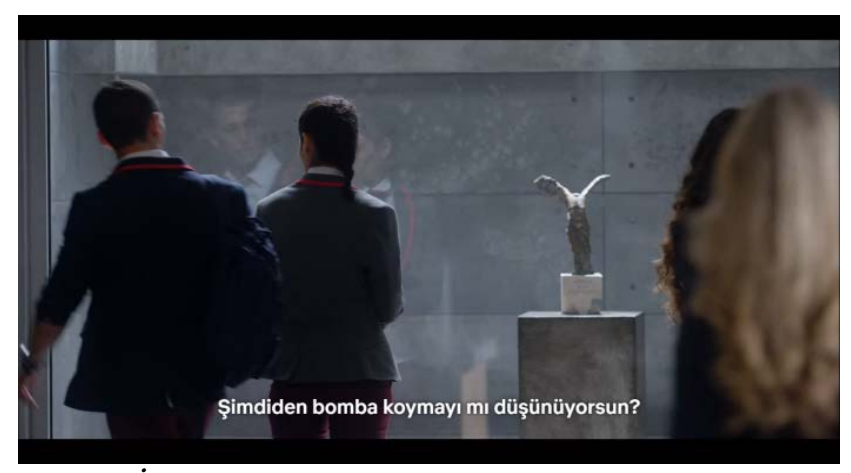

İmaj 4. Christian Karakterinin Irkçı Söylemi

\section{Christian Karakterinin 1. Söylemi:}

- Merhaba güzelim

- Şey. Pardon.

- Öyle dedim diye intihar bombacısı olma...

\section{Christian Karakterinin 2. Söylemi:}

- Şimdiden bomba koymayı mı düşünüyorsun?

Nadya, Christian karakteriyle birlikte Las Encinas okuluna eğitime ilk başlama gününde tanışma fırsatı yakalamışlardır. Nadya'nın sosyokültürel bağlamda kendi Müslüman ve Arap kimliğini temsil eden bir simge olarak 
algılanabilecek "hijab" başörtüsü taktığı görülmektedir. Bu durumda dişarıdan kimliğinin ve hassasiyetlerinin rahatlıkla algılanabileceği açıtır. Bu konumda olan Nadya' ya bulunduğu ülkenin genel ideolojik kodlarına sahip çeşitli uzantıların ırkçı söylemlerde bulunma, onu dışlama ve hatta zor kullanma gibi davranışlar sergileyebilmesi olası bir durum olarak görünmektedir. Tüm bunlara rağmen okulda ilk etapta dini inancına ait geleneksel başörtüsü takan Nadya Christian tarafından ırkçı söylemlere maruz kalmıştır. Christian'ın ürettiği söylem iki sahnede de "intihar bombacısı" sıfatıdır. Bir batılı tarafından Müslüman ve/veya Arap kimliğiyle bağdaştırılabilecek sıfatlardan birisi "intihar bombacısı" olmaktadır. Sosyokültürel bağlamda Battdaki bir ülkede başörtüsü takanlar için oluşacak ilk algı onların intihar eylemleri düzenleme kapasitesine sahip birer "bombacı" olmaları durumudur. Birinci ırkçı söylemden sonra yine Christian karakterinin filmin başka bir sahnesinde ürettiği ikinci ırkçı söylem de birincisinin uzantısı durumundadır. İkinci sahnede zorunlu olarak milli ve manevi unsuru olan hijabını çıkaran Nadya yine de Christian karakteri tarafından ırkçı söylemlere maruz kalmaktan kurtulamamaktadır. Irkçı söylemlerin bu aşamada kimliğe yapışan bir yapısının olduğu da ortaya çıkmıştır ve ısrarla ırkçı sıfatlar Nadya karakterine yapıştırılmaktadır.

Sinematografik açıdan incelendiğinde ise yönetmenin bu söylemlerin oluştuğu sahnelerde Nadya'yı çerçevenin altın oransal bölümlerinde tutmak yerine sahnenin sağ tarafında ya da sol tarafında önemsiz alanlarda tutmaktadır. Bu görsel düzenlemedeki unsurla birlikte aslında ırkçı söylem normalleştirilmiştir. Bulunulan ülkede, toplum arasında her zaman konuşulan ve normal olan söylemdir, bunun için kimsenin itiraz etmesine gerek görülmemektedir. 


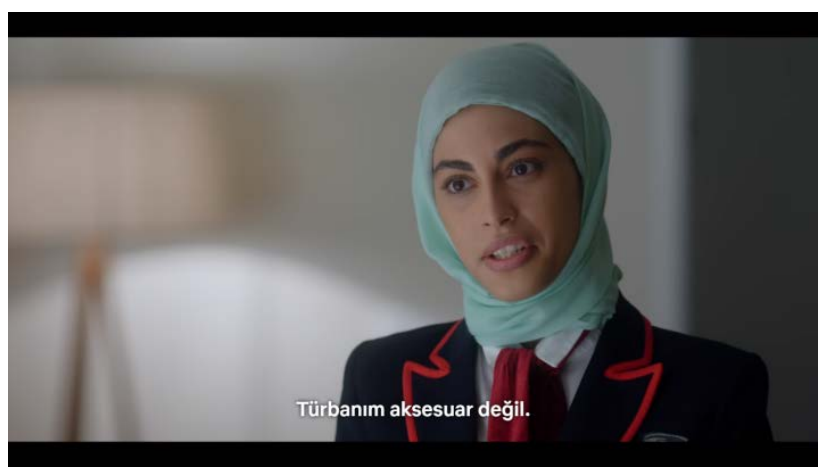

İmaj 5. "Hijab" Nedeniyle Ötekileştirilen Nadya

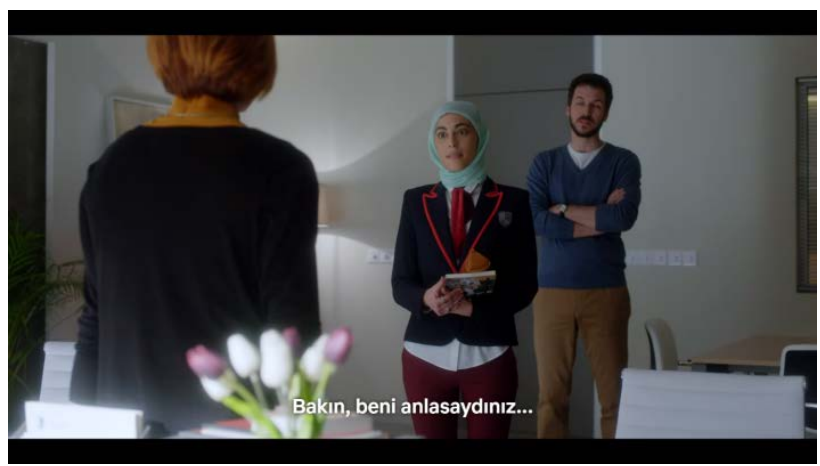

İmaj 6. "Hijab" Nedeniyle Ötekileştirilen Nadya

\section{Azucena Karakterinin Söylemi:}

- Daha önce kimse başörtüsünden bahsetmemişti, Şimdi nereden çıktı? (Nadya)

- Kurallarımız gereği aksesuara izin yok. (Azucena)

- Türbanım aksesuar değil. Hem herkes aksesuar takıyor. Pahalı çantalar, altın saatler. (Nadya)

- Onlar süs amaçlı, bir anlama gelmiyorlar.(Azucena)

- Geliyorlar, çok anlama geliyorlar: Senden daha çok param, senden daha tarzım senden daha iyiyim...(Nadya)

- Nadya seni gerçekten anlıyoruz ama biz...(Martin)

- Beni gerçekten anlasaydınız, kültürümden ya da dinimden vazgeçmemi istemezdiniz. (Nadya)

- Nadya bunu düşün, karar senin ama yarında bu şekilde takıp gelirsen, seni atmaktan başka çaremiz kalmaz. (Azucena) 
Nadya karakteri kolejde "hijab" olarak adlandırılan, Arap coğrafyasında ve Filistin'de yoğun şekilde kullanılan geleneksel başörtüsünü takmaktadır. Dini inancını ve kültürel kodlarını yansıtan "hijab" içselleştirdiği değerlerinin sosyokültürel alanda dişa vurumu olmaktadır. Büyük çoğunluğu Hristiyan olan bir ülkede ve özellikle seçkin iş insanlarının çocuklarının eğitim gördüğü büyük bir kurumda bu simge rahatsızlık yaratmaktadır. Sosyokültürel bağlamda, aşırı eğlencenin, madde kullanımının, serbest şekilde yaşanan cinsel deneyimlerin ve çarpık ilişkilerin karşısında kendi kimliğini konumlandıran Nadya ve onun geleneksel başörtüsü sistemin ideolojik kodlarına karşıdır. Dolayısıyla ülkenin ideolojik algılayış yapısının uzantısı okul yöneticisi Azucena karakteri için de başörtüsü bir dinsel ve/veya urksal simgedir ve sistem açısından tehdit oluşturmaktadır. Azucena'nın ırkçı bağlamdaki söyleminin temelini atan ötekileştirme söyleminin köklerine bakıldığında Avrupa'nın ideolojik yapısı öne çıkmaktadır. Avrupa'nın ideolojik kodlarına göre başörtüsü kendi kültürler kodlarının karşısında duran, kaygı verici ve militarist bir simge olarak tasarlanmıştır. Bu Avrupa ideolojisinin arketip köklerinde ise sömürgeci tahakkümün yansımaları görülmektedir. "Baş örtüsü, İslam militanlığındaki 'endişe verici' yükseliş iddialarını desteklemek için görsel bir ipucu görevi görüyor. Dünyadaki Müslüman kadınların böylesine bozulmuş bir imajı işgal etmeleri için zemin, on dokuzuncu ve yirminci yüzyıllarda, Avrupalı sömürgecilerin yönettikleri ve yer aldığı yerli kültürleri yıkmak ve yok etmek için 'öteki' kadını özgürleştirmeye takıntılı hale geldiklerinde atılmıştır (Spencer, 2006, s. 126). Sinematografik unsurların da ırkçı söylem kodlarını destekler bir yapıda kurulduğu görülmektedir. Sahnenin ilk planında eğitim kurumunun yöneticisi Azucena karakteri çerçevenin altın oransal bölünmesinde önemli değer atfedilecek bir figürde çerçevelenmiştir. Ayrıca bu sahnenin son planında, kendinden önceki planları destekleyecek biçimde Azucena ve Martin karakterleri kadrajin önünde ve arkasında konumlandırılmışlardır. İki otorite arasında sıkışık biçimde kalan karakter ise etnik ve dinsel ayrımcılığa uğrayan Nadya'dır. İdeolojik baskı aracı ve ülkedeki otoritenin uzantısı Azucena ve Martin' in söylemsel baskısı, sinematografik araçlarla ve sahne konumlandırılmasıyla da sağlamlaştııılmıştır. 


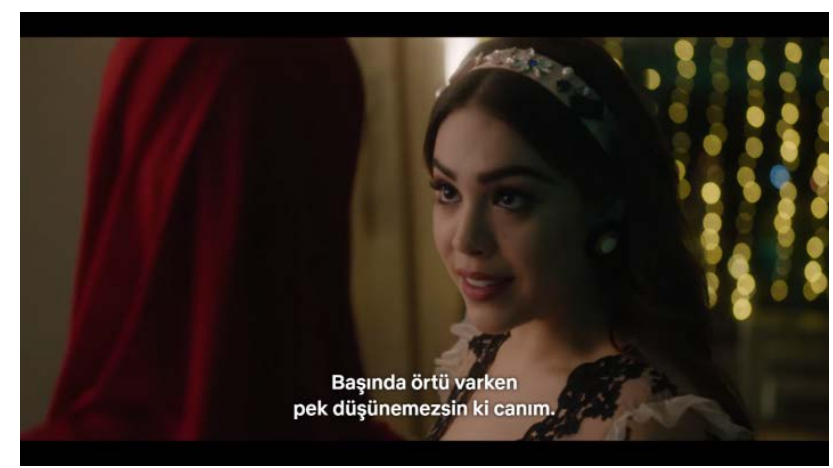

İmaj 7. Lu Karakterinin Irkçı Söylemleri

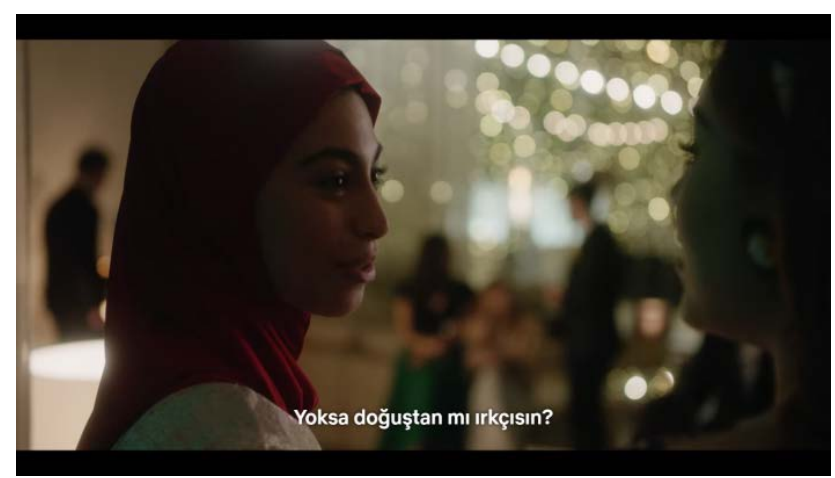

İmaj 8. Lu Karakterinin Irkçı Söylemleri

\section{Lu Karakterinin Söylemi:}

- Bu ortam ancak alkolle çekilir, buyur. (Lu)

- Teşekkür ederim, ben içmiyorum. (Nadya)

- Gecen zor geçecek desene. (Lu)

- Yakında çıkarım. (Nadya)

- Hepimizi çoktan yargılamışken, neden bize bir şans tanıyasın değil mi? (Lu)

- Batı hakkında nefret ettiğin ne varsa hepsi burada değil mi? Tüm o günahkar dejenerasyon. (Lu)

- Ben yargılıyordum hani? Görüyorum ki ne düşündüğüme karar vermişsin. (Nadya)

- Başında o örtü varken pek düşünemezsin ki canım. (Lu)

- Konu şampanya içmek istememem mi? Yoksa doğuştan mı 1rkçısın? (Nadya) 
-...Sana bir tavsiye canım, her şey için zaman vardır, mesela bana bak çocuklarla çıkıyorum, eğleniyorum. (Lu)

Nadya, sınıf arkadaşlarının davetine istinaden onların düzenlediği partiye geleneksel tarzdaki başörtüsünü takarak gelmiştir. Toplumsal ortamdan uzak kalmamak adına yorumlanabilecek bu davranış ayrıca Nadya'nın görünen geleneksel ve dinine bağlı kimliğini koşulsuz olarak tanıtma ve bir özne olarak var olabilme mücadelesinin de sessiz bir tezahürüdür. Sınıf arkadaşı Lu karakterinin partide Nadya'nın yanına gelerek onun öteki kimliğini reddetmesine yönelik tahakküm edici, tek tipleştirici ve ırkçı söylemlerde bulunduğu görülmektedir. Bu çerçevede Lu'nun sosyokültürel bağlamda ve özgürlük çatısı altında dayattığı davranış kalıpları "içki içmek, erkeklerle takılmak, eğlenmek" şeklinde olmaktadır. Bu davranıs kalıplarının sosyal mecrada pratiğe dökülmemesi ve başörtüsü takılması Avrupa'nın değerlerine terstir. Avrupai değerler çatısı altında "sosyal uyum-sosyal entegrasyon" süreçlerinin sağlıklı işlemesi ve sosyal çevreye uyum sağlanmasının en önemli koşulu doğuştan getirilen milli ve dini kimliğin reddedilerek yerine Avrupai tarzda yaşam kalıplarını ve ideolojiyi benimseyen bir kimliğin kazanılmasıdir.

Yönetmenin filmde Avrupa'daki arketipsel yaşam kalıplarını ideolojik olarak sanatsal imajlarla yeniden üretme arzusu bu sahnede de pekiştirilmiştir. Lu karakterinin Nadya'ya Avrupai değerleri dikte ederken kullandığ ırkçı söylemlere sinematografik ögelerle de destek verildiği göze çarpmaktadır. Lu karakteri konuşurken, çerçeveye alındığında yüzü ışık kaynaklarına dönük durumda ve daha iyi aydınlatılmış şekillerde vurgulanırken Nadya ise hafif ters ışıkta yüzüne daha az ışık kaynağının düştüğü bir pozisyonda daha karanlık gösterilmiştir. Ayrıca Lu Nadya'yı dinlerken yan profilden yüzü görülecek şekilde gösterilirken, Nadya Lu'yu dinlerken ise başörtüsünün tamamıyla kafasını kapattığı, tam arka profilden gösterilmiştir. Böylece asıl özne ve karar verici merci, ülkenin ırkçı söylemler üretebilen ve sözde değerlerini koruyabilen kesimleridir, ötekilerin ve farklı dine mensupların özneliği işlevsizleştirilerek yıkıma uğratılmıştır. Bu doğrultuda Müslüman bir mülteci ırkçı söylemlere maruz kalmayı hak eder pozisyonda, sinematografik ögelerle desteklenmiştir. 


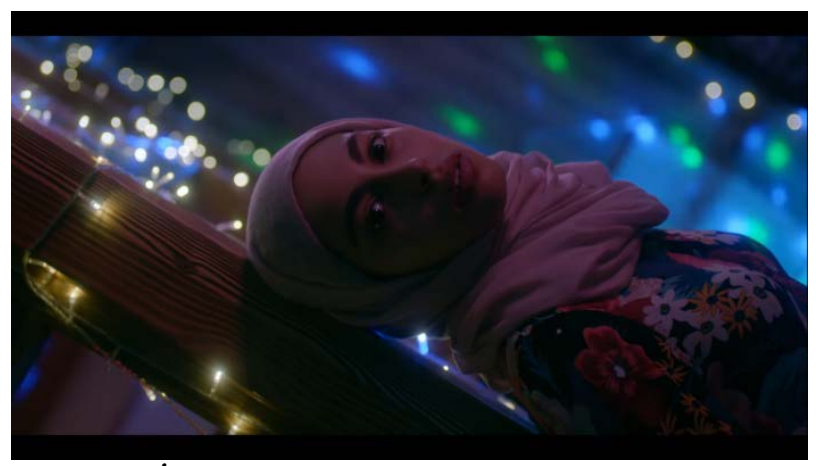

İmaj 9. Nadya'nın Değişime Uğraması

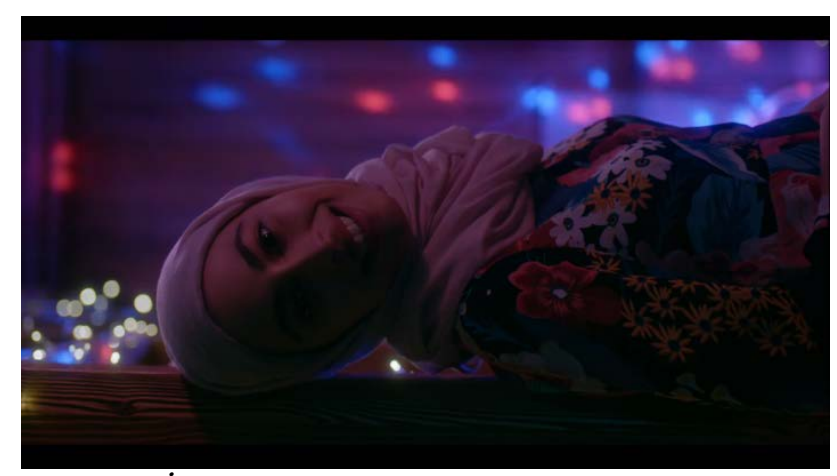

İmaj 10. Nadya'nın Değişime Uğraması

Elite filminin ilerleyen bölümlerinde kültürel ve manevi değerlerinden ödün vermemeye çalışan, bir yandan da kendini sosyal ortamlardaki eğlence aktivitelerine katılarak da olsa varlığının tanınmasını arzulayan Nadya kültürel değer orijininden kısmen çıkmış biri olarak figüre edilmiştir. Eğlence ortamında kazara içmiş olduğu içki aslında bizlere, Avrupa'nın ideolojik sisteminde ne yaparsa yapsın farklı değerlere sahip bir mülteci çocuğunun hiçbir koşulda genel ideolojik değer kodlarına karşı gelemeyeceğini ve onların pasif bir nesne olduklarını dikte etmektedir. Bu durumda asıl benimsenmesi gereken şey, Avrupai değerlerin ideolojisiyle, eğlencesiyle, yaşam tarzıyla birlikte bütüncül bir şekilde benimsenmesidir.

Sahnenin başında eğik bir kadrajla, başı dönmüş ve mutsuz yüz ifadesiyle gösterilen Nadya kadrajın normalleşmesiyle birlikte yüz ifadesi çok mutlu bir şekilde dönüşüme uğramıştır. Sinematografik araçların da seferber edildiği 
bu sahnede, başlarda biraz direnç göstererek ideolojik kodlara karşı gelen Nadya artık Batı́nın ideolojik özgürlük uzantısı olan eğlence kültürüne sahip bir bireyi haline gelmiştir. Sosyokültürel anlamda da entegrasyonunu sağlamış ve normalleşen kadraj aslında onu da normalleştirmiştir. Daha önce Nadya'nın tercih ettiği değerler ve içselleştiremediği sosyal etkileşimi Batı için bir eğridir ve bu sahnede düz bir hale getirilerek mutlu k1lınmıştır. Irkçı söylemlerden sonra böyle bir sahnenin çekilmesi ırkçı ideolojik kodları idealleştirme mahiyetinde olmaktadır.

\section{Sonuç}

Toplumda üretilen söylem biçimleri bize ideoloji, güç unsurları, tahakküm, sosyal konumlandırma gibi alanlarla ilgili çeşitli fikirler verebilmede önemli bir inceleme alanıdır. Bu inceleme alanı yalnızca metinsel düzlemdeki söylemlerden ibaret olmamakla birlikte aynı zamanda toplumun gerçekliğini kısmen de olsa gösterebilme yeteneğine sahip sinema sanatı içinde inceleme alanı oluşturmaktadır. Çok boyutlu toplumsal söylem kodlarının, ideolojik bir perspektifle yansıtılabildiği film dünyası konumu itibariyle bu ideolojik kodları estetize ederek sunabilme kabiliyetine sahiptir.

Tıpkı metinlerde bulunan ideolojik kodları, güç ilişkilerini ve sosyokültürel bağlamı eleştirel bir bakış açısıyla ortaya çıkarabilmek için kullanılabilecek bir yöntem olan eleştirel söylem analizi, film dünyasının içerisinde üretilen söylem kodlarını da çözümleyebilecek bir yol olabilmektedir. Fakat yalnızca eleştirel söylem analiziyle sinematik evrende üretilen kodları açımlamak mümkün olmayabilmektedir. Bu hususta söylem kodlarının köklerine inebilmek amacıyla aynı zamanda sinematografik çözümleme perspektifinden söylemsel kodlara bakmak yararlı olacaktır.

Eleştirel söylem analizinin önemli bir parçası da etnisiteye dayalı ayrımcılık yani ırkçılıktır. Irkçılığın yakın çağda özellikle batı toplumlarında yükselmesine rağmen çeşitli ideolojik argümanlarla ve sanatın farklı alanlarında normalleştirilerek sunulduğu görülmektedir. Irkçı söylemleri sinematografik unsurlarla destekleyerek normalleştiren sanat alanı sinema olmaktadır. Hızla akan imajlar ve söylemler içerisinde oldukça zengin bir kod üretme kapasitesine sahip olan filmler, söylemi yönetmenin çerçevesini çizdiği dolayımsal bir düzende, estetik algılara hitap edecek şekilde cazipleştirirler. Filmlerde ideo- 
loji çerçevesinde sunulan ırkçı kodların da özellikle avrupai bakış açısıyla izleyiciye rahatsızlık vermeden gösterilmesi mümkün kılınmaktadır. Hassasiyetle hazırlanan ideolojik ve sosyokültürel kodların çözümlenmesini de aynı hassasiyetle, Fairclough'un eleştirel söylem çözümlemesinin "çok boyutlu söylem" modeliyle, yani söylemin üretim sürecini ve yorum sürecini sosyokültürel bağlamda (durumsal, kurumsal, sosyal) irdeleyerek söylemsel kodları açımlamak mümkün olmaktadır. Aynı zamanda sşık, çerçevelendirme, renk gibi sinematografik ögeleri de işin içine alarak sonuca gidilebilmektedir. Bu doğrultuda Netflix'te yer alan Elite dizi filmi kapsamında, Nadya karakteri üzerinden irdelenen ırkçı söylemlerle birlikte aslında insanları cezbeden ve avrupai arzu olarak nitelenen değerlerin de altyapısında nefret ve normatif bağlamlarda bir etnosentrizm olduğu göze çarpmaktadır. Bu ırkçı ve ideolojik uzantıların idealize edildiği yer ise dijital platformlarda yer alan filmlerdir.

Sinema dünyasının çok katmanlı anlam oluşturma potansiyeli ve bu minvalde kullandığı sosyokültürel kodlar filmlerde ışık, renklendirme, ve çeşitli ölçeklendirme biçimleriyle de estetize edilerek bilinçlere sunulur. Normal hayatta heterojen olarak kendi içlerinde bile birbirlerinden ayrı vasıflarda olan göçmenler ve yabancilar, filmsel dünyada homojenleştirilerek sunulmakta ayrıca zihinlerde negatif stereotip algıları oluşturulmaktadır.

Farklı yerlerden gelen ve/veya farklı dinlere mensup karakterlerin Netflix platformundaki Batı orijinli sinema yapımlarında bulunan bazı filmlerde ötekileştirilerek sunulduğu göze çarpmaktadır. Ayrıca bu karakterlerin etnosantrik bakışlarla öznelliklerinin tahrip edidiği veya tamamen nesneleştirilen bir konumda pasifize edildikleri ortaya çımaktadır.

Dünya çapındaki ülkeler holokost soykırımından beri ırkçılık veya nefret söylemi gibi unsurları sinema filmlerinde veya çeşitli görsel araçlarla alenen kullanamamaktadırlar (Jodar \& Maria, 2018). Bu nedenle bu tür ögeler çeşitli sinematik metaforlarla ve sinematografik anlam dünyasıyla mevcut ülkelerin ürettiği filmlerin anlatım kodlarına eklemlenerek sunulmaktadır. Sinematografik araçlarla söylem düzlemini arkasına alan sunuş biçimi bunlardan biri olarak görülebilmektedir. Böylece ideolojik anlam evreninde ırkçılık bağlamında mevcut toplumsal yapının sürekliliği sağlanmaktadır. 


\title{
EXTENDED ABSTRACT
}

\section{Critical Discourse Analysis of 'Elite' TV Series in the Context of Racism}

\author{
* \\ Mustafa Oğuz Yeğin \\ Niğde Ömer Halisdemir University
}

Cinema is at least as effective and powerful as other media tools in terms of imposing its ideology and consciousness on the masses and changing and transforming them. Films highlight the effectiveness of discourse in terms of producing and developing meaning, and using this various possibilities of camera angles, sound, montage and effects, they include us in an attractive artistic atmosphere that has the effective use of visual rhetoric and is a unique world of imagination.

Ryan and Kellner (2010, p. 34-35), the world of film; social arguments, social structure connection representations and relations are encoded as a form of encryption. Thus, it becomes possible for films to encode the discourses of social life in various ways and convey them to the audience through cinematic figures. Cinema is an artistic activity that contributes to the production of people living in society, rather than signs isolated from society. As a result of all these, it is the whole of images that enables the transmission of different discursive levels in society. In addition, in terms of the analysis of the discourse, considering that the general representations of society are reflected in the cinema, it is argued that analyzes should be made by establishing the relationship between this and the working order of the society. From all these points of view, one of the ways to analyze the main meaning in movies is discourse analysis.

"Critical Discourse Analysis" is necessary to explain the discourse codes that are ideologically embedded in Cinema Films in various ways. This method was preferred in order to analyze the ideological connections and power relations of the discourse specifically for the Elite TV series. The discursive analysis of Nadya Character's experiences during her first enrollment in Spanish school is based on the first five episodes in which the character's adaptation to the school is in the context of "racist discourse". In the study, Fairclough's "Critical Discourse Analysis" method was used to analyze the 
racist discursive codes in the film, and "Cinematographic Analysis" method was used to show which cinematic technical details the ideology was presented in the film.

Film art is an art made using a camera and many cinema techniques. But films tend to show the director's "ideal ideology" in the society he grew up in and within himself, rather than showing the "reality" in the society as it is. "From the moment we start shooting a movie, from the very first shot, we are faced with the obligation to reproduce things not as they really are, but as they are filtered by ideology. This includes every stage in the production process: subjects, styles, forms, meanings, narrative traditions; all of these emphasize the general ideological discourse. Film is an ideology that presents itself, speaks to itself, and learns itself "(Comolli \& Narboni, 1976, p. 25).

According to Fairclough, in many previous studies in the context of ideology, how the relations of domination and loyalty to power work have been questioned frequently. In addition, various inquiries have been made regarding the role of ideology in the relations between ethnic groups in social relations. Although there is no deterministic situation about the functioning of ideology, criticism of ideology is a field of struggle for various social groups and ethnic structures. CDA and hence "critical language awareness" is positioned as an important way of ideological criticism (Fairclough, 1995, p. 1718).

Fairclough expresses the three-dimensional understanding of discourse and the three-dimensional Critical Discourse Analysis method he has created in this context as follows: text interpretation), (iii) sociocultural practice "(2013, p. 151). In this method, the linguistic definition of the language text (productive and interpretive) includes the interpretation of the relationship between discursive processes and the text, and the explanation of the relationship between discursive processes and social processes (Fairclough, 2013, p. 152). While analyzing the discourses in the films, it is possible to reach important clues about the relations of the linguistic text in the social context.

Discourses based on heterogeneous and complex social relations enable us to reach existing sociocultural and ideological codes (Fairclough, 2013, pp.151-153). In addition to the image, the dialogues of characters and types also take a large place in film art. For this reason, it would not be wrong to consider movies as rich visual and textual resources. Therefore, it is possible that we can critically conduct "texts" and "sociocultural" discourse practices 
that Fairclough mentions in his discourse analysis, in the context of various films, on an analytical level, based on the dialogues in the Film World.

It is the aim of this study to show how the codes of "racist discourse" actively produced in the society are supported by films as well, with the critical discourse analysis that Fairclough guided by taking the sociocultural context and multidimensional interpretation process as the basis of the "Elite" series movie. The analysis of ideological and racist codes in the films is not only content with using critical discourse analysis, but also the cinematographic analysis method was added to the study to show how cinematic codes support these racist discourses.

\section{Kaynakça / References}

Adorno, T. W. (2007). Kültür endüstrisi kültür yönetimi. (N. Ülner, M. Tüzel, \& E. Gen, Çev.) İstanbul: İletişim Yayınları.

Blanco, J. M., ve Ortega , T. (2018). Fears and prejudices of a nation. The figure of black in the recent history of spain through the cinema (1959-2002). Historia Social, 131-148.

Blanco, M., ve Lopez, T. (2017). The figure of a black through the big screen. The entry of Spain into the European Union as the turning point. Historia y comunicacion social, 567-583.

Bordwell, D., ve Thompson, K. (2008). Film art: An introduction. New York: The McGraw-Hili Companies Inc.

Bulmer, M., ve Solomos, J. (1999). Racism. New York: United States by Oxford University Press Inc.

Charles, E., ve Wilson, J. (2005). Race and racism in literature. London: Exploring Social Issues Through Literature Greenwood Press.

Comolli, J., ve Narboni, J. (1976). Cinema/Ideology/criticism, movies and methods, Berkeley: University of Califomia Press. (B. Nichols, Dü.) Berkeley: University of Califomia Press.

Çoruk, A. Ş. (2007). Oryantalizm üzerine notlar. Afyon Kocatepe Üniversitesi Sosyal Bilimler Dergisi, 9(2), 204-216.

Dedeoğlu, G. (2013). Medya ve iletişim çalışmalarında Teun A. Van Dijk'ın yaklaşımı. Nişantaşı Üniversitesi Sosyal Bilimler Dergisi, 1(3), 38-58.

Dijk, T. A. (1991). Racism and the press. London: Routledge.

Diken, B., ve Laustsen, C. B. (2011). Filmlerle Sosyoloji. İstanbul: Metis.

Durna, T., ve Kubilay, Ç. (2010). Söylem kuramları ve eleştirel söylem çözümlemeleri. T. Durna içinde, Medyadan Söylemler içinde (s. 47-83). İstanbul: Libra Yayıncllk. 
Fairclough, N. (1993). Discourse and social change. Cambridge: Polity Press in Association with Blackwell Publishing.

Fairclough, N. (1995). Critical discourse analysis: The critical study of language. New York: Published in the United States of America by Longman.

Fairclough, N. (2013). Critical discourse analysis. New York: Routledge is an imprint of the Taylor \& Francis Group.

Fekete, L. (2009). A suitable enemy: Racism, migration and Islamophobia in Europe. London: Pluto Press .

Foucault, M. (2003). İktidarın gözü. (I. Ergüden, Çev.) İstanbul: Ayrıntı Yayınları.

Frampton, D. (2013). Filmozofi. (C. Soydemir, Çev.) İstanbul: Metis Yayınları.

Goncalves, M. (2016). Transnational orientalisms in contemporary Spanish and Latin American Cinema. Cambridge: Cambridge Scholars Publishing.

İmdb Corporation. (2020, Haziran 20). Imdb https://www.imdb.com/title/tt7134908/fullcredits?ref =ttrel ql 1 adresinden alındı

Jodar, L., ve Maria, A. (2018). Neo-racism and its manifestation in the cinema. Publicaciones Didacticas, 35-41.

Jung, J. (1980). The archetypesand the collective unconscious. New Jersey: Princeton University Press At Princeton.

Özer, Ö. (2009). Eleştirel haber çözümlemeleri. Eskişehir: Anadolu Üniversitesi İletişim Bilimleri Fakültesi Yayınları.

Plothe, T., ve Buck, A. (2019). Netflix at the Nexus content, practice, and production in the age of streaming television. New York: Peter Lang Publishing.

Pramaggiore, M. (2008). Tom Wallis Film, A critical introduction. Boston: Pearson Publishing Company.

Ramberg, I. (2004). Islamophobia and its consequences on Young People. Islamophobia in Europe: from the Christian anti-Muslim prejudice to a modern form of racism. Mr Vincent Geisser. Budapest: Published by the Directorate of Youth and Sport. G. Vincent içinde, Islamophobia in Europe: from the Christian anti-Muslim prejudice to a modern form of racism İçinde (s. 36-46). Budapest.

Ranciere, J. (2010). Özgürleşen seyirci. (E. B. Şaman, Çev.) İstanbul: Metis Yayınları.

Ryan, M., ve Kellner, D. (2010). Politik Kamera: Çă̆daş Hollywood sinemasının ideolojisi ve politikası. (E. Özsayar, Çev.) İstanbul: Ayrıntı Yayınları.

Ryan, M., ve Lenos, M. (2014). Film çözümlemesine giriş: Anlatı sinemasında teknik ve anlam. (E. S. Onat, Çev.) Ankara: De Ki Yayınları.

Scollon, R. (2001). Action and Text: Towards an integrated understanding of the place of text in social (Inter)action. R. Wodak, e M. Meyer, Medhods of Critical Discourse Analysis içinde (s. 140-168). London: Sage. 
Spencer, S. (2006). Race And ethnicity: culture, identity and representation,Abindgdon. Abindgdon: Routledge is an Imprint of the Taylor \& Francis Group.

TDK. (2020, Haziran 28). Türk Dil Kurumu Sözlï̈̆̈̈. https://sozluk.gov.tr/ adresinden alındı

Wayne, M. (2011). Sinemayı anlamak, marksist perspektifler. (E. Yulmaz, Çev.) Ankara: De Ki Yayınları.

Webtekno. (2021, Ocak 2). Netflix Nedir? Televizyondan Netflix Nasl İzlenir?: https://www.webtekno.com/netflix-nedir-televiyondan-nasil-izlenirh87660.html adresinden alınd 1

Wodak, R., ve Meyer, M. (2009 ). Critical discourse analysis: History, agenda, theory, and methodology. Los Angeles: Sage Publications.

Yaylagül, L. (2004). 1960-1970 dönemi Türk Sinemasında düşünce akımları. F. Dalay, \& A. Gürata, Sinemada Anlatı ve Türler içinde (s. 232). Ankara: Vadi Yayınları.

\section{Kaynakça Bilgisi / Citation Information}

Yeğin, M. O. (2021). Irkçıllk bağlamında 'Elite' dizi filminin eleştirel söylem analizi. OPUS-Uluslararası Toplum Araştırmaları Dergisi, 17(34), 1487-1521. DOI: 10.26466/opus.816234 